UDC 339.5[665:33.012](477)

DOI: $10.15673 /$ fie.v12i1.1663

\author{
Antonyuk 0. \\ Ph.D., Associate Professor \\ Department of Accounting and Auditing \\ Odesa National Academy of Food Technologies \\ Kanatna str., 112, Odesa, Ukraine, 65039 \\ E-mail: olegantoni@ukr.net \\ ORCID ID: 0000-0002-9182-4982 \\ Stupnytska T. \\ Ph.D., Associate Professor \\ Department of Accounting and Auditing \\ E-mail: t.stupnitska@gmail.com \\ ORCID ID: 0000-0002-2517-2795 \\ Antonyuk P. \\ Ph.D., Researcher \\ Department of Market Mechanisms and Structures \\ Institute of Market Problems and Economic \& Eco- \\ logical Research of National Academy of Sciences of \\ Ukraine \\ Frantsuzskiy boulevard, 29, Odesa, Ukraine, 65044 \\ E-mail: paul_antonyuk@ukr.net \\ ORCID ID: 0000-0002-8100-2563 \\ Volodina 0. \\ Assistant \\ Department of Foreign Languages \\ Odesa National Academy of Food Technologies \\ Kanatna str., 112, Odesa, Ukraine, 65039 \\ E-mail: volodinaolenaonaft@gmail.com \\ ORCID ID: 0000-0003-0552-6733
}

\title{
FOREIGN TRADE OF OIL FOOD COMPLEX PRODUCTS IN THE CONDITIONS OF INTEGRATION OF UKRAINE
}

The article examines the current tendencies of entering the oil and fat subcomplex of Ukraine into the world markets. It has been revealed that oil crops and their products are the main export commodity in agro-food export of the state. The large scale production of the sub-complex products, with modest domestic consumption, is first and foremost associated with successful integration into international trade. Foreign trade thus becomes an important factor in the development of the subcomplex. Considering the complexity and multidimensionality of the problem, the main segments of the market - oilseeds, oils and oilcake - are highlighted in the research. On the basis of statistical data, the analysis of export volumes, dynamics, position on the world market and opportunities for their strengthening were made. It has been established that Ukraine, as a powerful producer and active participant in the world market, influences, to some extent, the excess of world production over consumption of oil and products of their processing, which leads to a decrease in export prices and, as a consequence, to a loss of export earnings of domestic exporters. The study substantiates the need to improve the structure of production of oilseeds, the balance of use of soybeans and rapeseed, constant monitoring of the situation in foreign markets.

Key words: integration, oil and fat subcomplex, export, import, export price, oilseeds, oils, oilcake, world market.

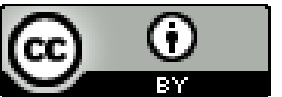

This work is licensed under a Creative Commons Attribution 4.0 International License http://creativecommons.org/licenses/by/4.0/
Statement of the problem and its connection with important scientific and practical tasks. In the context of Ukraine's integration into the world economic system, foreign trade problems are of particular importance, which is especially important for industries focused mainly on exporting their products. For Ukraine, it is first and foremost the production of the fat-oil subcomplex, which is the main export commodity in agrofood exports. In 2018, agri-food provided \$ 18612 million dollars, including $\$ 7325$ million dollars or $39.3 \%$ of sales of oilseeds and their products. In recent years, the growth rates of exports of oil and fat products and oil raw materials have been declining significantly, which, with significant exports, may indicate a certain depletion of export potential. Thus, if during the period 2009-2013 the average annual growth rate of exports was at the level of
$120.5 \%$, in $2014-2018$ this figure decreased to $103.7 \%$. The need to further increase exports of oil and fat subcomplex products on the basis of raising production efficiency, improving the commodity structures of both oil and products of their processing determine the relevance of this study.

The analysis of the latest publications on the problem. Problems of development of international trade in agro-food products are always at the center of economic research of many domestic scientists, namely: $\mathrm{M}$. P. Butka, V. S. Godin [2], N. A. Karasova [4], Yu. O. Lupenko [8], T. O. Ostashko [5], M. I. Pugacheva [6], S. A. Szegeda [7] and others. However, the conducted research focuses mainly on the analysis of the state of export of all agri-food products and the prospects for its expansion, but insufficient attention is paid to solving 
problems with the export of certain types of products. The identification of opportunities to maintain and strengthen positions in the world markets for those types of products, is of particular relevance the realization of these products forms a significant part of Ukrainian exports and, in the first place, the production of the fat and fat subcomplex.

Forming of the aims of the research. The purpose of this study is to evaluate the export status of oilseeds and their processing products as constituents of agri-food products, and to substantiate proposals for a more rational use of existing resources to strengthen positions in the global market.
Giving an account of the main results and their substantiation. In recent years, the process of integration into the world economic processes of Ukraine, whose economy in the past has been somewhat closed, has intensified. An important factor of economic integration is foreign trade and first of all increase of export of goods. A special place in the increase of commodity exports is occupied by the products of the agro-food complex, which since 2014 has become the main export commodity of the state [1]. Agro-food products include the production of the oil and fat sub-complex: oilseeds sunflower, soybean, rapeseed, and products of their processing - oils and oilcake, which make up a significant part of Ukraine's agro-food exports (table 1).

Table 1

Export of products of oil-fat sub-complex of Ukraine *

\begin{tabular}{|l|c|c|c|c|c|}
\hline \multicolumn{1}{|c|}{ Indicators } & 2009 & 2016 & 2017 & 2018 & $\begin{array}{c}2018 \text { at } \% \\
\text { to } 2009\end{array}$ \\
\hline All exports of goods, million USD & 39703 & 36362 & 43265 & 47335 & 119,2 \\
Export of agri-food products, mln USD & 9515 & 15284 & 17758 & 18612 & 195,6 \\
Exports of oil and fat subcomplex products USD million & 2874 & 6203 & 7359 & 7325 & 254,9 \\
including - oilseeds & 950 & 1454 & 1971 & 1870 & 196,8 \\
- oils & 1649 & 3885 & 4480 & 4377 & 265,4 \\
- oilcake & 275 & 864 & 908 & 1078 & 392,0 \\
The share of production of oil-fat sub-complex (\%) & & & & & \\
- in total exports & 7,2 & 17,1 & 17,0 & 15,5 & x \\
- in export of agri-food products & 30,2 & 40,6 & 41,4 & 39,4 & x \\
\hline
\end{tabular}

* Calculated by the authors according to the Ukraine State Statistics Service [3]

Exports of oil and fat sub-complex goods are growing much faster than exports of both agri-food and all commodity exports. As a result, over the last ten years - 2009-2018, their share increased in exports of all goods from $7.2 \%$ to $15.5 \%$, and in agri-food exports from $30.2 \%$ to $39.4 \%$. On average, in $2016-2018$, the share of oil and fat subcomplex goods in agri-food exports is $40.4 \%$, against $38.1 \%$, which is attributable to grain and maize. That is, in the agri-food export from Ukraine in recent years, the leading positions are occupied by the production of the oil and fat subcomplex, in which oil crops and products of processing enterprises are distinguished - oil and oilcake, whose exports are growing much faster than the export of oil raw materials. And the main export commodity in the composition of the oil and fat subcomplex is industrial production. From 2016-2018 export revenues, in the amount of 20887 million dollars, 15592 million dollars or $74.6 \%$ accounted for oils and oilcakes, which exceeded the 2009 figure of $66.9 \%$.

In the export of oil raw materials, which occupies a quarter of the exports of the oil and fat subcomplex in recent years, there was the largest revenue from the sale of soybeans and rapeseed, as sunflower is exported in small quantities. Regarding the structure of export of industrial products - here the products of sunflower (oil and oilcake) prevail. In terms of crops, the largest export revenue is for seeds and sunflower processing products. But in this regard, there are positive changes, with the share of sunflower falling from $72.6 \%$ in 2009 to $68.6 \%$ in 2018 , while the export of soybean oil, oilseeds and rape seeds has increased.
The achieved export volumes are the result of deep integration into the world economic processes, creation of a modern highly efficient, export-oriented branch of the Ukrainian economy and supply of domestic raw material resources.

During this period 60 new enterprises were created, as well as existing ones were reconstructed and modernized. Total investment in the industry exceeded \$ 3 billion dollars.

Oil processing capacity has increased from 2.5 million tons per year in 1998 to 26 million tons in 2018, or by 10.4 times, incl. the processing of sunflower - 20 million tons, soybeans - 4 million tons and rapeseed - 2 million tons. The created capacity for processing of sunflower already exceeds the gross fees by 1.5 times, which may require the beginning of import of raw materials.

The functioning of the oil market depends primarily on the size of the gross levy and the main directions of its use - domestic consumption, exports, imports, which are strongly influenced by state policy. Data on the production of oilseeds in the period of 1990-2018 are given in table 2 .

Table the data of 2 show that during the period of independence, the production of oilseeds has made significant progress - gross harvest has increased by 7.6 times, mainly due to increase in acreage by 4.9 times and to a lesser extent due to sunflower yield, which though increased by $144.3 \%$, soybean - by 2.3 times and rape by $168.4 \%$, but inferior to the level of such EU countries as France, Germany, Romania, Italy [16]. 
Table 2

Production of basic oilseeds in Ukraine for 1990-2018 *

\begin{tabular}{|l|c|c|c|c|c|c|c|c|c|}
\hline \multirow{2}{*}{ Years } & \multicolumn{2}{|c|}{ Sown area, thousand ha } & \multicolumn{2}{c|}{ Gross collection, thousand tons } & \multicolumn{3}{c|}{ Yield, kg / ha } \\
\cline { 2 - 9 } & Sunflower & Soybean & Rape & Sunflower & Soybean & Rape & Sunflower & Soybean & Rape \\
\hline 1990 & 1636 & 89 & 84 & 2571 & 99 & 130 & 15,8 & 11,1 & 15,5 \\
2000 & 2842 & 61 & 157 & 3457 & 64 & 132 & 12,2 & 10,6 & 8,4 \\
2005 & 3743 & 438 & 207 & 4706 & 613 & 285 & 12,8 & 14,5 & 14,6 \\
2010 & 4572 & 1076 & 907 & 6772 & 1680 & 1470 & 15,0 & 16,2 & 17,0 \\
2015 & 5105 & 2158 & 682 & 11181 & 3931 & 1738 & 21,6 & 18,4 & 25,9 \\
2016 & 6073 & 1869 & 455 & 13627 & 4277 & 1154 & 22,4 & 23,0 & 25,7 \\
2017 & 6034 & 2000 & 789 & 12236 & 3899 & 2195 & 20,2 & 19,7 & 27,9 \\
2018 & 6117 & 1717 & 1052 & 14165 & 4460 & 2746 & 22,8 & 25,8 & 26,1 \\
\hline
\end{tabular}

* Calculated by the authors according to the Ukraine State Statistics Service [3]

The increase in oil yields should be considered as an important reserve for increasing the gross harvest even in the face of reduced acreage that already exceeds the allowed limits. In Ukraine, an extremely high level of crop saturation with oilseed crops has grown from 5.6\% in 1990 to $32.0 \%$ in 2018 . The situation is quite rare in the world. Thus, in the European Union, where rapeseed, sunflower and soybeans are the main oilseed crops, 11977 thousand hectares or $9.1 \%$ of the acreage was occupied in 2017 [17]. Despite significant growth in soybean and rapeseed production in Ukraine, sunflower re- mains the main oil crop, although its share has declined from $91.8 \%$ of total oil production in 1990 to $66.3 \%$ in 2018.

With the production volumes of sunflower, soybean and rapeseed far exceeding the needs of the domestic market, Ukraine is becoming an important player in the global market for oilseeds and their products. In recent years, Ukraine is the largest producer of sunflower in the world with a share of about $25 \%$ of the total world production (table. 3 ).

Table 3

The world's major producers of sunflower seeds, million tons *

\begin{tabular}{|c|c|c|c|c|}
\hline \multirow{2}{*}{ Countries } & \multicolumn{4}{|c|}{ Marketing years } \\
\hline & $2015 / 2016$ & $2016 / 2017$ & $2017 / 2018$ & $2018 / 2019$ \\
\hline Ukraine & 11,2 & 13,6 & 12,2 & 14,2 \\
\hline Russian Federation & 9,7 & 11,6 & 11,0 & 12,7 \\
\hline European Union & 7,7 & 8,5 & 9,8 & 9,5 \\
\hline Argentina & 2,8 & 3,3 & 3,4 & 3,7 \\
\hline Others & 11,5 & 12,9 & 12,7 & 12,4 \\
\hline Total & 42,9 & 49,8 & 49,1 & 52,5 \\
\hline
\end{tabular}

* Compiled by authors based on sources [3, 15]

Almost all sunflower crop is processed at domestic enterprises, and a small part of it is exported. In $2015-2018$, only 376 thousand tons or $0.7 \%$ of the production volume was exported. The main importers are the countries of the European Union and Turkey.

Unlike sunflower, soybean and rapeseed production is largely export oriented. In 2010-2018 Ukraine significantly increased soybean production and came out on top in Europe. As domestic consumption of soybeans is much less than the volume of exports, Ukraine's position on the world market is stronger in exports than in its production. Ukraine is ranked eighth in the world by volume of soybean production, and sixth in terms of export after five such powerful soybean exporters as Brazil, USA, Argentina, Paraguay, Canada [14]. The main export destination for soybean exporters from Ukraine is Asia 4040 thousand tons in $2016-2018$, or $51.5 \%$ of total exports. Three major importers stand out on this continent, accounting for 3811 thousand tons of deliveries during this period, or $94.3 \%$ of this area, including: Turkey 2388 thousand tons; Iran - 1067 thousand tons; Lebanon 356,000 tons. The European Union is the world's second- largest soybean importer (13-16 million tons), in the last three years it imported 1708 thousand tons of soybean (less than Turkey), accounting for $21.8 \%$ Ukrainian exports. Restrictions on imports of soybeans from Ukraine by the European Union are attributed to the suspected production of genetically modified soybean varieties in our country. It is suggested that half of soybean is genetically modified in Ukrainian fields [11]. The main importers from the EU countries of the Ukrainian soybean in 2016-2018 are: Italy - 354 thousand tons, Greece - 337 thousand tons, the Netherlands - 271 thousand tons and Poland - 212 thousand tons which account for $68.7 \%$ of Ukrainian exports to EU countries. Third place in Ukrainian exports is Africa, which is mainly represented by Egypt. However, during this period, Egypt significantly reduced the purchase of Ukrainian soybeans from 840 thousand tons in 2016 to 419 thousand tons in 2017 and 171 thousand tons in 2018 , ie almost by 5 times. Important soybean importers from Ukraine are CIS countries, mainly Belarus, which account for more than $95 \%$ of the CIS imports. Ukrainian exports of soybean to Belarus increased from 92 thousand tons in 2016 to 152 thousand 
tons in 2017 and to 355 thousand tons in 2018 , or by 3.8 times [3].

In the last two years, there has been a significant increase in rapeseed production in Ukraine, allowing it to gain a foothold in the sixth place in the world, where the main producers are the EU and Canada. India and China, Australia are by a large margin. In world production, the share of Ukraine in $2017-2018$ is about $4.0 \%$. In the world export of rapeseed, which averaged 16.5 million tons in 2017/2018 and 2018/2019, the share of Ukraine is in the range of $14-15 \%$, which allows it to be among the top three rapeseed exporters after Canada and Australia. To date, rapeseed production in Ukraine is mainly focused on exports - 2136 thousand tons in 2017 and 2440 thousand tons in 2018, which is respectively $97.3 \%$ and $88.9 \%$ of output. Traditionally, the main export flows of rapeseed are sent to the European Union, one of the largest importers of this crop in the world, with an average annual import volume of about 4.2 million tons in 20162018.

In 2018, Ukraine exported 2140 thousand tons of rapeseed to the EU, which is more than half of their imports. During 2015-2018, the largest importers with the volume of imports were the following countries: Belgium - 1582 thousand tons, Germany - 1348 thousand tons, France - 1094 thousand tons and the Netherlands - 952 thousand tons. In total, they accounted for $84,2 \%$ of Ukrainian rapeseed. The second, but much smaller in terms of imports from Ukraine were Asian countries - in 2015-2018 1035 thousand tons, or $14.8 \%$ of Ukrainian exports. Pakistan, the United Arab Emirates, Israel and Bangladesh are the main as well as constant buyers [3].

Ukraine not only exports oilseeds, but also makes significant purchases of seed, mainly sunflower seeds. These costs are becoming traditional in agri-food imports with a tendency to increase - table 4.

Table 4

Imports of oilseeds material *

\begin{tabular}{|l|c|c|c|c|}
\hline \multirow{2}{*}{ Oilseed crops } & \multicolumn{3}{|c|}{ Imports, million dollars } & \multirow{2}{*}{2018 at \% to 2016} \\
\cline { 2 - 5 } & $2016 \mathrm{p}$. & $2017 \mathrm{p}$. & $2018 \mathrm{p}$. & 125,4 \\
Sunflower & 206,0 & 230,3 & 258,3 & 65,7 \\
Soybeans & 3,5 & 2,5 & 2,3 & 142,7 \\
Rape & 22,7 & 32,1 & 32,4 & 126,2 \\
& 232,2 & 264,9 & 293,0 & \\
\hline
\end{tabular}

* Calculated by the authors according to the Ukraine State Statistics Service [3]

As can be seen, the import of seeds is dominated by sunflower seeds, and sunflower and rapeseed purchases are constantly increasing. Only soybean purchases are reduced.

It should be noted that import costs are quite significant and account for 18-19\% of imports of plant products. These imports are characterized by a high concentration of clearly identified suppliers [12]. The seeds of sunflower are mainly purchased by Turkey, USA, France, soybeans - Canada, Czech Republic. Today, Ukraine imports dozens of times more seeds than it exports. Such significant dependence on imports poses a certain threat to the national economy.
Vegetable oils - sunflower, rapeseed and soybean, and above all sunflower oil, which accounts for 93$96 \%$ of the revenue from vegetable oils, provide the largest export revenue from the sale of oil and fat subcomplex products. Ukraine is the world leader in the production and export of sunflower oil [18]. Today, Ukraine accounts for more than a third of world production of these products and about $56 \%$ of world exports. In the second place among the world exporters with a share of $21 \%$ of the world market is Russia, which is a serious competitor for our exporters. Export volumes of vegetable oils from Ukraine are given in table 5.

Export of plant oils for 2014-2018*

Table 5

\begin{tabular}{|l|c|c|c|c|c|c|}
\hline \multicolumn{1}{|c|}{ Indicators } & 2014 & 2015 & 2016 & 2017 & $\begin{array}{c}2018 \\
2018 \text { at \% } \\
\text { to } 2014\end{array}$ \\
\hline 1. Sunflower oil, thousand tons & 4339 & 3938 & 4842 & 5757 & 5585 & 128,7 \\
including crude oil, thousand tons & 4093 & 3685 & 4523 & 5299 & 5145 & 125,7 \\
Share, \% & 94,3 & 93,6 & 93,4 & 92,0 & 92,1 & x \\
2. Soybean oil, thousand tons & 122 & 154 & 153 & 166 & 215 & 176,2 \\
3. Rapeseed oil, thousand tons & 101 & 148 & 92 & 64 & 144 & 142,6 \\
\hline
\end{tabular}

* Calculated by the authors according to the Ukraine State Statistics Service [3]

Over the past five years, exports of soybean and rapeseed oil have grown at a rapid rate, bringing their share in vegetable oil exports from $4.9 \%$ in 2014 to $6.0 \%$ in 2018 . More than $99 \%$ in soybean exports and rapeseed oil is crude unrefined oil. The main importing countries for soybean oil are China and Poland, and rapeseed oil is the EU and China. Ukraine has significant capacity to increase both the production and export of soybean and rapeseed oils, taking into account the capacity of the importing country, significant raw materials and available soybean and rapeseed processing capacity, currently only $20 \%$ loaded. 
Sunflower oil is now shipped from Ukraine to more than 120 countries. The main export destinations are Asian countries, which in 2014-2018 imported 68.1\% of oil from Ukraine. The main importers from the continent are India, China and Iran. EU countries account for
$25 \%$ of Ukrainian exports over the same period. Spain, the Netherlands, Italy, France and the United Kingdom are among the most important importers. The rating of the largest importers of crude sunflower oil is given in table 6 .

Table 6

The largest importers of unrefined sunflower oil from Ukraine *

\begin{tabular}{|c|c|c|c|c|c|c|c|c|}
\hline \multicolumn{3}{|c|}{2014} & \multicolumn{3}{|c|}{2016} & \multicolumn{3}{|c|}{2018} \\
\hline № & Countries & $\%$ in exports & № & Countries & $\%$ in exports & № & Countries & $\begin{array}{c}\% \text { in ex- } \\
\text { ports }\end{array}$ \\
\hline 1. & India & 41,5 & 1. & India & 33,9 & 1. & India & 47,8 \\
\hline 2. & China & 9,7 & 2. & China & 13,8 & 2. & China & 8,8 \\
\hline 3. & Iran & 7,0 & 3. & Netherlands & 8,7 & 3. & Spain & 6,3 \\
\hline 4. & Egypt & 5,3 & 4. & Spain & 8,0 & 4. & Netherlands & 6,2 \\
\hline 5. & Spain & 5,1 & 5. & Italy & 6,8 & 5. & Italy & 5,9 \\
\hline 6. & Netherlands & 4,6 & 6. & Iran & 6,2 & 6. & Iran & 3,1 \\
\hline 7. & Turkey & 4,5 & 7. & France & 3,4 & 7. & France & 2,0 \\
\hline 8. & Italy & 4,3 & 8. & Turkey & 3,3 & 8. & United Kingdom & 2,0 \\
\hline 9. & Algeria & 2,0 & 9. & Egypt & 2,7 & 9. & Egypt & 1,9 \\
\hline 10. & Saudi Arabia & 1,7 & 10. & Malaysia & 1,6 & 10. & Turkey & 1,4 \\
\hline
\end{tabular}

India is the main buyer of Ukrainian oil, increasing its purchases annually - from 1700 thousand tones in 2014 to 2458 thousand tones in 2018 , despite the increase by the Government of India of import duties on vegetable oils to support domestic production. In some cases, Ukraine is losing its position in the sunflower oil market. Thus, in 2018, Ukraine exported to Egypt 100 thousand tons of sunflower oil, which is by 3.5 times less than in 2013 - 355 thousand tons and Egypt dropped from third to ninth place in the rating of importing countries of Ukrainian crude oil . The reasons for such a significant decrease were the decrease in the consumption and import of sunflower oil, the increase in the production and consumption of soybean oil, the increase in the import of oil from Russia at a price that suits importers more. Due to increased production and exports of sunflower oil, Russian exporters can significantly squeeze competitors in the export markets, including the Chinese market, at a lower price - \$20 per ton, although the quality of Ukrainian products is higher.

As can be seen from the data in table. 5, over $92 \%$ of exported oil is unrefined oil, which is explained by the structure of production. In the total production of refined and unrefined oil in 2017, refined oil amounted to 723.6 thousand tons, or only $12.1 \%$. When there is an excess of the production of refined oil over domestic consumption, much of the production is exported. In recent years, the volume of exports is estimated at 400-450 thousand tons, which is only about $8 \%$ of total exports. The main importers are the Asian countries, including the largest of them: Malaysia, UAE, Jordan, Lebanon. Imports from four EU countries came from four countries Belgium, Italy, the Netherlands, and Poland.

If Ukraine is firmly a leader in the world market for unrefined oil, the situation is different in the refined oil market. In this market, Ukraine ranks fourth, and Turkey, one of the main importers of crude oil from Ukraine, ranks first. The total capacity of refined sunflower oil in the world market is estimated at approximately $\$ 3.9$ billion. Ukrainian exports are worth about \$ 310 million. This means that Ukrainian sunflower oil producers should focus on this particular product category [9].

Ukraine can change its position on the world market due to the increase in export of high-oleic sunflower oil. There is increasing demand in the world for this type of product, which is even more olive in content than oleic acid. Global demand for such products is estimated at 2.5 million tones, including the EU market about 800 thousand tones. Ukraine is at the beginning of developing such a market - the processing capacity of high-oleic sunflower is only 500 thousand tones, and exports of high-oleic sunflower oil is not marked by special volumes and stability: - in 2017 - 210 thousand tons, in 2018 - 185 thousand tons. It should be noted that the stable development of oil and fat subcomplex in the part of sunflower oil production is possible only under conditions of export duty on sunflower seeds .

The need for protein products is increasing in the world and Ukraine is stepping up its role in supplying oilcake to the world market. An estimate of the production and export of oilcake is presented in table 7.

For the period 2014-2018, both production and export of oilcake, both as a whole and by species, has been increasing. Exports of sunflower cake during this period amounted to $96.3 \%$ of its production volume. Rapeseed cake is fully exported, and soybean cake is more than a third. Due to stagnation of domestic demand in Ukraine, both export volumes and its share in production are increasing. With such export volumes of sunflower cake, Ukraine holds a dominant position in the world market with a share of about $65 \%$ with total export of sunflower cake in the world of about 7 million tons. Despite the increase in production and export of soya bean meal and rapeseed oilcake, Ukraine's position in the world market is quite modest. 
Table 7

Dynamics of production volumes and exports of cakes *

\begin{tabular}{|c|c|c|c|c|c|c|}
\hline Types of cakes & 2014 & 2015 & 2016 & 2017 & 2018 & $\begin{array}{c}2018 \text { at } \% \\
\text { to } 2014\end{array}$ \\
\hline \multicolumn{7}{|c|}{ Production, thousand tons } \\
\hline Sunflower & 3851 & 3625 & 4280 & 5011 & 4936 & 128,2 \\
\hline Soybeans & 721 & 783 & 831 & 852 & 1022 & 141,7 \\
\hline Rapeseed & 116 & 155 & 107 & 74 & 153 & 131,9 \\
\hline Total & 4688 & 4563 & 5218 & 5937 & 6111 & 130,4 \\
\hline \multicolumn{7}{|c|}{ Export, thousand tons } \\
\hline Sunflower & 3791 & 3496 & 3983 & 4800 & 4297 & 113,3 \\
\hline Soybeans & 109 & 262 & 334 & 307 & 415 & 3,8 p. \\
\hline Rapeseed & 115 & 150 & 102 & 74 & 151 & 131,3 \\
\hline Total & 4015 & 3908 & 4419 & 5181 & 4263 & 121,1 \\
\hline \multicolumn{7}{|c|}{ Export at $\%$ of production } \\
\hline Sunflower & 98,4 & 96,4 & 93,1 & 95,8 & 87,1 & $\mathrm{x}$ \\
\hline Soybeans & 15,1 & 33,5 & 40,2 & 36,0 & 40,6 & $\mathrm{x}$ \\
\hline Rapeseed & 99,1 & 96,7 & 95,3 & 100,0 & 98,7 & $\mathrm{x}$ \\
\hline Total & 85,6 & 85,6 & 84,7 & 87,3 & 79,6 & $\mathrm{x}$ \\
\hline
\end{tabular}

* Calculated by the authors according to the Ukraine State Statistics Service [3]

The largest importers of oilcake are EU countries. Over the last three years, $56.4 \%$ of sunflower cake (Spain, Italy, Netherlands, Poland), $80.5 \%$ of rapeseed (Spain, Lithuania, Poland) and $33 \%$ of soybean (Poland, Hungary) have been exported there. A large amount of oilcake is imported from Asia. In 2016-2018, 24.1\% of sunflower seeds - Israel, Turkey - were exported to the continent, and in 2018, China, which imported 619 thousand tones, was the largest volume compared to other importers. In previous years, China was not interested in procurement from Ukraine, but the situation changed as a result of a trade conflict between the US and China, when it became necessary to look for an alternative to US soybean and rapeseed cake [13]. Important importers in this period are the CIS countries - $43.5 \%$ of Ukrainian exports of soybean cake and $12.6 \%$ of sunflower. Almost all CIS exports come from Belarus. A promising market is Africa
(Morocco, Egypt), which accounted for $6.8 \%$ of Ukraine's exports of sunflower cake.

It should be noted that production and export volumes depend to a large extent on the global market conditions, including the level and dynamics of prices. Over the last five years, there has been an increase in production over the consumption of vegetable oils, which negatively affects the prices of oilseeds and products of their processing [10]. So for the period 2013/2014 MP and 2018/2019 MP the price of soybean oil decreased from $\$ 950$. for 1 ton to $\$ 760$ per ton, or $20 \%$. Soybean is the main oilseed crop for the market, it is mostly produced in the world. Therefore, reducing the price of soybean oil causes a decrease in prices for other oilseeds and their products. The level and dynamics of export prices for the production of oil-fat sub-complex of Ukraine are given in table 8 .

Table 8

The level of export prices for oilseeds and products of their processing in exports of Ukraine for 2014-2018*

\begin{tabular}{|c|c|c|c|c|}
\hline \multirow[t]{2}{*}{ Product } & \multicolumn{3}{|c|}{ Export price, USD / t } & \multirow{2}{*}{2018 at \% to 2014} \\
\hline & 2014 & 2016 & 2018 & \\
\hline Oilseeds: & & & & \\
\hline Sunflower & 594 & 384 & 480 & 80,8 \\
\hline Soy & 420 & 360 & 371 & 88,3 \\
\hline Rape & 428 & 395 & 414 & 96,7 \\
\hline Oil: & & & & \\
\hline Sunflower & 818 & 765 & 736 & 90,0 \\
\hline Soybeans & 785 & 730 & 710 & 90,4 \\
\hline Rapeseed & 824 & 747 & 773 & 93,8 \\
\hline Oilcake: & & & & \\
\hline Sunflower & 237 & 183 & 205 & 86,5 \\
\hline Soybeans & 511 & 347 & 390 & 76,3 \\
\hline Rapeseed & 237 & 194 & 225 & 94,9 \\
\hline
\end{tabular}

* Calculated by the authors according to the Ukraine State Statistics Service [3]

Despite some growth in some export price positions in 2017-2018 compared to 2016, the price level in
2014 was unattainable. In addition, the main export commodity of sunflower oil and soybean prices continues 
In such circumstances, an increase in export earnings is ensured by an increase in the physical volume of exports. Indeed, the increase in exports of oil and fat subcomplex products from \$ 6329 million. in 2014 to \$ 7325 million in 2018 , or $115.7 \%$ was accompanied by an increase in the physical volume of exports from 12361 thousand tonnes in 2014 to 15547 thousand tonnes, or by $125.8 \%$ in 2018 . That is, losses from a decrease in export prices are offset by growth in production and exports of these kinds of products. Taking into account the existing opportunities for increasing yields and increasing the gross collection of oilseeds, as well as the insufficient level of utilization of processing capacities in Ukraine, there are reserves for further increasing the production of oilseeds and their products. The question remained is what level of world prices will turn out to be the limit beyond which the increase in Ukrainian exports will not be able to compensate for further price reductions.

Conclusions and prospects of the further investigations. During the period 2009-2018, exports of oil and fat subcomplex products increased by 2.5 times, and in recent years in agri-food exports of Ukraine, the products of the subcomplex occupy leading positions, even ahead of cereals and maize. Today, Ukraine is becoming an important exporter in certain segments of the global market for oilseeds and their products. However, the increase in quantitative indicators of production and export of products is not always accompanied by an increase in quality. As a result, in some respects, extensive directions prevail, which limits the ability to increase exports.
Further development of foreign trade in the products of the oil and fat sub-complex, preservation of existing positions on the world market requires qualitative improvement in both the raw material and industrial sectors of the sub-complex:

- in the production of oilseeds, the priority should be to increase the yield to the level of the EU countries, which opens the possibility of reducing acreage, reducing the burden on the ground, especially at the expense of sunflower;

- structural changes in the composition of oilseeds should predict an increase in the proportion of soybeans and rapeseed, while reducing the proportion of sunflowers;

- the increase in the export value of sunflower oil is really possible due to the increase in the export of both conventional refined oil and high-oleic oil;

- the balance of use of soybean and rapeseed in the direction of increasing its processing at domestic enterprises and exports of finished products requires a significant change;

- constant monitoring of the situation on foreign markets for oil and oilcake should enable timely detection and response to changes in these markets in order to avoid or reduce losses of export earnings;

Further research on the oil and fat subcomplex may be a more detailed assessment of individual segments of the oilseed market and their products.

\section{References}

1. Antoniuk, P. O., Antoniuk, O. P., Stupnytska, T. M., \& Holovachenko, L. M. (2019). Stan ta rezultaty torhivli ahroprodovolchymy tovaramy mizh Ukrainoiu ta Yevropeiskym Soiuzom. Food Industry Economics, 11(1), 2736. doi: 10.15673/fie.v11i1.1292

2. Butko, M. P., \& Rodin, V. S. (2010). Ahropromyslova intehratsiia yak shliakh aktyvizatsii ahrarnoho vyrobnytstva. Ahrosvit, (3), 10-13. Retrieved from http://nbuv.gov.ua/UJRN/agrosvit_2010_3_3

3. Derzhavna sluzhba statystyky Ukrainy. Retrieved January 10, 2020, from http://www.ukrstat.gov.ua/

4. Karasova, N. A. (2014). Hlobalizatsiihi determinanty eksportooriientovanoho rozvytku ahrarnoho sektora Ukrainy. Mizhnarodna Ekonomichna Polityka, (1 (20), 129-152.

5. Ostashko, T. O. (2016). Eksport ahroprodovolchykh tovariv u YeS: perspektyvy i zavdannia. Ekonomika $i$ Prohnozuvannia, (1), 83-93. doi: 10.15407/eip2016.01.083

6. Puhachov, M. I. (2019). Rozvytok zovnishnoi torhivli ahroprodovolchymy tovaramy. Ekonomika APK, (3), 06-12. doi: 10.32317/2221-1055.201903006

7. Seheda, S. A. (2019). Ahrarno-prodovolcha produktsiia v tovarnii strukturi zovnishnoi torhivli Ukrainy. Ekonomika APK, (2), 73-82. doi: 10.32317/2221-1055.201902073

8. Lupenko, Yu. O., \& Puhachov, M. I. (Eds.). (2015). Formuvannia hlobalnoho i rehionalnoho rynkiv silskohospodarskoi syrovyny ta prodovolstva. Kyiv: NNTs «IAE».

9. Doslidzhennia rynku soniashnykovoi olii v Ukraini. (2016). Retrieved January 10, 2020, from koloro.ua/ua/blog/issledovaniya/issledovanie-rynka-podsolnechnogo-masla-v-ukraine.html

10. Mirovyie tsenyi na rastitelnyie masla upali do desyatiletnego minimuma: chem eto grozit Ukraine. (2018). Retrieved January 12, 2020, from 1k.com.ua/mirovye-tseny-na-rastitelnye-masla-upali-do-desyatiletnego-minimumachem-eto-grozit-ukraine.html

11. Na ukrainskih polyah polovina soi geneticheski modifitsirovannaya - issledovaniya. (2018). Retrieved January 12, 2020, from www.unian.net/economics/agro/10323291-na-ukrainskih-polyah-polovina-soi-geneticheskimodificirovannaya-issledovanie.html

12. Osnovnym postachalnykom nasinnia soniashnyku v Ukrainu ye Turechchyna. (2019). Retrieved January 12, 2020, from www.unn.com.ua/uk/news/1785431-osnovnim-postachalnikom-nasinnya-sonyashniku-v-ukrayinu-yeturechchina 
13. Tendentsii eksporta ukrainskogo podsolnechnogo masla i shrota v 2018/2019 MG. (2018). Retrieved January 10, 2020, from s-s-s.com.ua/blog/stati/tendentsii-eksporta-ukrainskogo-podsolnechnogo-masla-i-shrota-v-2018-19mg

14. Top-10 eksporterov soi iz Ukrainyi 2018. (2019). Retrieved January 14, 2020, from latifundist.com/rating/top-10-eksporterov-soi-iz-ukrainy-2018

15. Chiffres cles oleagineux et plantes riches en proteins 2018. (2019). Retrieved January 14, 2020, from http://www.terresunivia.fr/sites/default/files/chiffres\%20c1\%C3\%A9s/TerresUnivia-chiffresCles-2018.pdf

16. Situation des marchés - FranceAgriMer. Retrieved January 14, 2020, from https://www.franceagrimer.fr/filiere-fruit-et-legumes/Eclairer/Etudes-et-Analyses/Informations-de-conjoncture

17. Statistiques Oléagineux et Plantes Riches en Protéines 2017. Retrieved January 10, 2020, from http://www.terresunivia.fr/sites/default/files/articles/publications/marches/statistiques-2017-oleagineux-plantes-richesproteines.pdf

18. L'Ukraine: plus gros exportateur mondial d'huile de tournesol. (2011). Retrieved January 12, 2020, from https://www.enerzine.com/lukraine-plus-gros-exportateur-mondial-dhuile-de-tournesol/13098-2011-10

Received 25 January 2020

Approved 8 February 2020 Available in Internet 31.03.2020

\author{
Антонюк О.П. \\ кандидат экономических наук, доцент \\ кафедра учета и аудита \\ Одесская национальная академия пищевых \\ технологий \\ ул. Канатная, 112, г. Одесса, Украина, 65039 \\ E-mail: olegantoni@ukr.net \\ ORCID ID: 0000-0002-9182-4982
}

\section{Ступницкая Т.M.}

кандидат экономических наук, доцент кафедра учета и аудита

E-mail: t.stupnitska@gmail.com

ORCID ID: 0000-0002-2517-2795

\begin{abstract}
Антонюк П.О.
кандидат економических наук, научный сотрудник отдел рыночных механизмов и структур

Институт проблем рынка и экономико-экологических исследований НАН Украины

Французский бульвар, 29, г.Одесса, Украина, 65044

E-mail: paul_antonyuk@ukr.net

ORCID ID: 0000-0002-8100-2563
\end{abstract}

Володина Е.П.

ассистент

кафедра иностранных языков

Одесская национальная академия пищевых технологий

ул. Канатная, 112, г. Одесса, Украина, 65039

E-mail: volodinaolenaonaft@gmail.com

ORCID ID: 0000-0003-0552-6733

\section{ВНЕШНЯЯ ТОРГОВЛЯ ПРОДУКЦИЕЙ МАСЛОЖИРОВОГО ПОДКОМПЛЕКСА В УСЛОВИЯХ ИНТЕГРАЦИИ УКРАИНЫ}

В статье исследуются современные тенденции вхождения продукции масложирового подкомплекса Украины на мировые рынки.

Выявлено, что в агропродовольственном экспорте страны основным экспортным товаром становятся масличные культуры и продукты их переработки - масло и шрот. Установлено, что значительные объемы производства продукции подкомплекса, которые в разы превосходят внутреннее потребление, являются результатом успешной интеграции в международную торговлю. Внешняя торговля, таким образом, становится решающим фрактором развития подкомплекса.

Учитывая сложность и многоаспектность проблемы, в исследовании выделены основные сегменты рынка - масличные культуры, масла и шрот. На основе статистических данных выполнен анализ объема и динамики экспорта, исследована география товарных потоков, определены позиции на мировых рынках и возможности их усиления.

В работе отмечается, что имеют место также значительные и постоянно возрастающие импортные поставки, прежде всего, семенного материала подсолнечника и рапса. Это необходимо для обеспечения достаточного уровня эффективности производства этих культур. Тем не менее такая зависимость от импорта, в условиях недостаточного развития отечественного семеноводства, представляет определенную угрозу для функционирования всего масложирового подкомплекса.

Установлено, что основные экспортные потоки продукции направляются в страны Азии, потребность рынка которых огромна, что открывает перед отечественными экспортерами возможности систематического наращивания экспорта. 
Определено, что Украина как мощный производитель и активный участник мирового рынка в определенной мере влияет на превышение мирового производства над потреблением масличных и продукции их переработки, что приводит к уменьшению экспортных цен и как следствие, к потерям экспортной выручки отечественных экспортеров.

В исследовании обоснована необходимость совершенствования производства масличных культур, баланса использования сои и рапса, постоянного мониторинга ситуации на внешних рынках.

Ключевые слова: интеграция, масложировой подкомплекс, экспорт, импорт, экспортная цена, масличные культуры, масло, шрот, мировой рынок.

\author{
Антонюк О.П. \\ кандидат економічних наук, доцент \\ кафедра обліку та аудиту \\ Одеська національна академія харчових технологій \\ вул. Канатна, 112, м. Одеса, Україна, 65039 \\ E-mail: olegantoni@ukr.net \\ ORCID ID: 0000-0002-9182-4982
}

Ступницька Т.M.

кандидат економічних наук, доцент кафедра обліку та аудиту

E-mail: t.stupnitska@gmail.com ORCID ID: 0000-0002-2517-2795
Антонюк П.О.

кандидат економічних наук, науковий співробітник відділ ринкових механізмів і структур

Інститут проблем ринку та економіко-екологічних досліджень НАН України

Французький бульвар, 29, м. Одеса, Україна, 65044

E-mail:paul_antonyuk@ukr.net

ORCID ID: 0000-0002-8100-2563

\section{Володіна О.П.}

асистент

кафедра іноземних мов

Одеська національна академія харчових технологій

вул. Канатна, 112, м. Одеса, Україна, 65039

E-mail: volodinaolenaonaft@gmail.com

ORCID ID: 0000-0003-0552-6733

\section{ЗОВНІШНЯ ТОРГІВЛЯ ПРОДУКЦІЄЮ ОЛІЄЖИРОВОГО ПІДКОМПЛЕКСУ В УМОВАХ ІНТЕГРАЦІЇ УКРАЇНИ}

В статті досліджуються сучасні тенденції входження продукції олієжирового підкомплексу України на світові ринки. Виявлено, що в агропродовольчому експорті держави основним експортним товаром стають олійні культури та продукти їх переробки - олії та макуха. Установлено, що значні обсяги виробництва продукції підкомплексу, які в рази перевищують внутрішнє споживання є результатом успішної інтеграції в міжнародну торгівлю. Зовнішня торгівля таким чином стає вирішальним фрактором розвитку підкомплексу. 3 огляду на складність і багатоаспектність проблеми в дослідженні виділено основні сегменти ринку - олійні культури, олії та макуха. На базі статистичних даних виконано аналіз обсягу та динаміку експорту, досліджено географрію товарних потоків , визначено позиції на світових ринках та можливостей їх посилення.

В роботі відзначається, що мають місце також значні і постійно зростаючі імпортні поставки, насамперед, насіннєвого матеріалу соняшнику і ріпаку. Це необхідно для забезпечення достатнього рівня ефективності виробництва цих культур. Проте така залежність від імпорту, в умовах недостатнього розвитку вітчизняного насінництва, становить певну загрозу для фрункціонування всього олієжирового підкомплексу.

Установлено, що основні експортні потоки продукції направляються в країни Азії, потреби ринку яких досить значні, що відкриває перед вітчизняними експортерами можливості систематичного нарощування експорту. Визначено, що Україна як потужний виробник і активний учасник світового ринку в певній мірі впливає на перевищення світового виробництва над споживанням олійних і продуктів їх переробки, що призводить до зменшення експортних цін і як наслідок, до втрат експортної виручки вітчизняних експортерів. В дослідженні обґрунтовано необхідність удосконалення виробництва олійних культур, балансу використання сої та ріпаку, постійного моніторингу ситуації на зовнішніх ринках.

Ключові слова: інтеграція, олієжировий підкомплекс, експорт, імпорт, експортна ціна, олійні культури, олії, макуха, світовий ринок. 


\section{Література}

1. Антонюк П.О., Антонюк О.П., Ступницька Т.М., Головаченко Л.М. Стан та результати торгівлі агропродовольчими товарами між Україною та Європейським Союзом // Економіка харчової промисловості. Том 11, Випуск 1/2019. С. 27-36. doi: 10.15673/fie.v11i1.1292

2. Бутко М. П., Родін В. С. Агропромислова інтеграція як шлях активізації аграрного виробництва // Агросвіт. 2010. № 3. С. 10-13. URL: http://nbuv.gov.ua/UJRN/agrosvit_2010_3_3. (дата звернення: 10.01.2020) 10.01.2020)

3. Державна служба статистики України: [Веб-сайт]. URL: http://www.ukrstat.gov.ua/ (дата звернення:

4. Карасьова Н.А. Глобалізаційгі детермінанти експортоорієнтованого розвитку аграрного сектора України // Міжнародна економічна політика. 2014. Вип. № 1 (20). С. 129-152.

5. Осташко Т.О. Експорт агропродовольчих товарів у ЄС: перспективи і завдання // Економіка і прогнозування. 2016. № 1. С. 83-93. doi: 10.15407/eip2016.01.083

6. Пугачов М.І. Розвиток зовнішньої торгівлі агропродовольчими товарами // Економіка АПК. 2019. № 3. С. 6-12. doi: 10.32317/2221-1055.201903006

7. Сегеда С.А. Аграрно-продовольча продукція в товарній структурі зовнішньої торгівлі України // Економіка АПК. 2019. № 2. С. 73-82. doi: 10.32317/2221-1055.201902073

8. Формування глобального і регіонального ринків сільськогосподарської сировини та продовольства: монографія / за ред. Ю. О. Лупенка, М. І. Пугачова. К.: ННЦ «ІАЕ», 2015. 320 с.

9. Дослідження ринку соняшникової олії в Україні: веб-сайт. URL: koloro.ua/ua/blog/issledovaniya/issledovanie-rynka-podsolnechnogo-masla-v-ukraine.html (дата звернення: 10.01.2020)

10. Мировые цены на растительные масла упали до десятилетнего минимума: чем это грозит Украине: веб-сайт. URL: 1k.com.ua/mirovye-tseny-na-rastitelnye-masla-upali-do-desyatiletnego-minimuma-chem-eto-grozitukraine.html (дата звернення: 12.01.2020)

11. На украинских полях половина сои генетически модифицированная - исследования: веб-сайт. URL: www.unian.net/economics/agro/10323291-na-ukrainskih-polyah-polovina-soi-geneticheski-modificirovannayaissledovanie.html (дата звернення: 12.01.2020)

12. Основним постачальником насіння соняшнику в Україну є Туреччина: веб-сайт. URL: www.unn.com.ua/uk/news/1785431-osnovnim-postachalnikom-nasinnya-sonyashniku-v-ukrayinu-ye-turechchina (дата звернення 12.01.2020)

13. Тенденции экспорта украинского подсолнечного масла и шрота в 2018/2019 MГ: веб-сайт. URL: s-s-s.com.ua/blog/stati/tendentsii-eksporta-ukrainskogo-podsolnechnogo-masla-i-shrota-v-2018-19-m (дата звернення: 10.01.2020)

14. Топ-10 экспортеров сои из Украины 2018 URL: latifundist.com/rating/top-10-eksporterov-soi-izukrainy-2018 (дата звернення: 14.01.2020)

15. Chiffres cles oleagineux et plantes riches en proteins 2018. URL: http://www.terresunivia.fr/sites/default/files/chiffres\%20cl\%C3\%A9s/TerresUnivia-chiffresCles-2018.pdf (дата 3вернення: 14.01.2020)

16. Situation des marchés - FranceAgriMer. URL: https://www.franceagrimer.fr/filiere-fruit-etlegumes/Eclairer/Etudes-et-Analyses/Informations-de-conjoncture (дата звернення: 14.01.2020)

17. Statistiques Oléagineux et Plantes Riches en Protéines 2017. URL: http://www.terresunivia.fr/sites/default/files/articles/publications/marches/statistiques-2017-oleagineux-plantes-richesproteines.pdf (дата звернення: (дата звернення: 10.01.2020)

18. L'Ukraine: plus gros exportateur mondial d'huile de tournesol. URL: https://www.enerzine.com/lukraineplus-gros-exportateur-mondial-dhuile-de-tournesol/13098-2011-10 (дата звернення: (дата звернення: 12.01.2020)

Стаття надійшла 25.01.2020

Стаття прийнята до друку 8.02.2020

Доступно в мережі Internet 31.03.2020

Цитування згідно ДСТУ 8302:2015

Antonyuk O., Antonyuk P., Stupnytska T., Volodina O. Foreign trade of oil food complex products in the conditions of integration of Ukraine // Food Industry Economics. 2020. Vol.12, Issue 1. P. 3-12. doi: 10.15673/fie.v12i1.1663

Cite as APA style citation

Antonyuk, O., Antonyuk, P., Stupnytska, T., \& Volodina, O. (2020). Foreign trade of oil food complex products in the conditions of integration of Ukraine. Food Industry Economics, 12(1), 3-12. doi: 10.15673/fie.v12i1.1663 